\title{
Adoption of Hybrid Maize Technology in District Mardan of Khyber Pakhtunkhwa, Pakistan
}

\author{
Murtaza, Shahid Ali*, Syed Attaullah Shah, Mehran Ahmad, Irfan Ullah and Jahangir Khan
}

Department of Agricultural and Applied Economics, The University of Agriculture, Peshawar, Khyber Pakbtunkbwa, Pakistan.

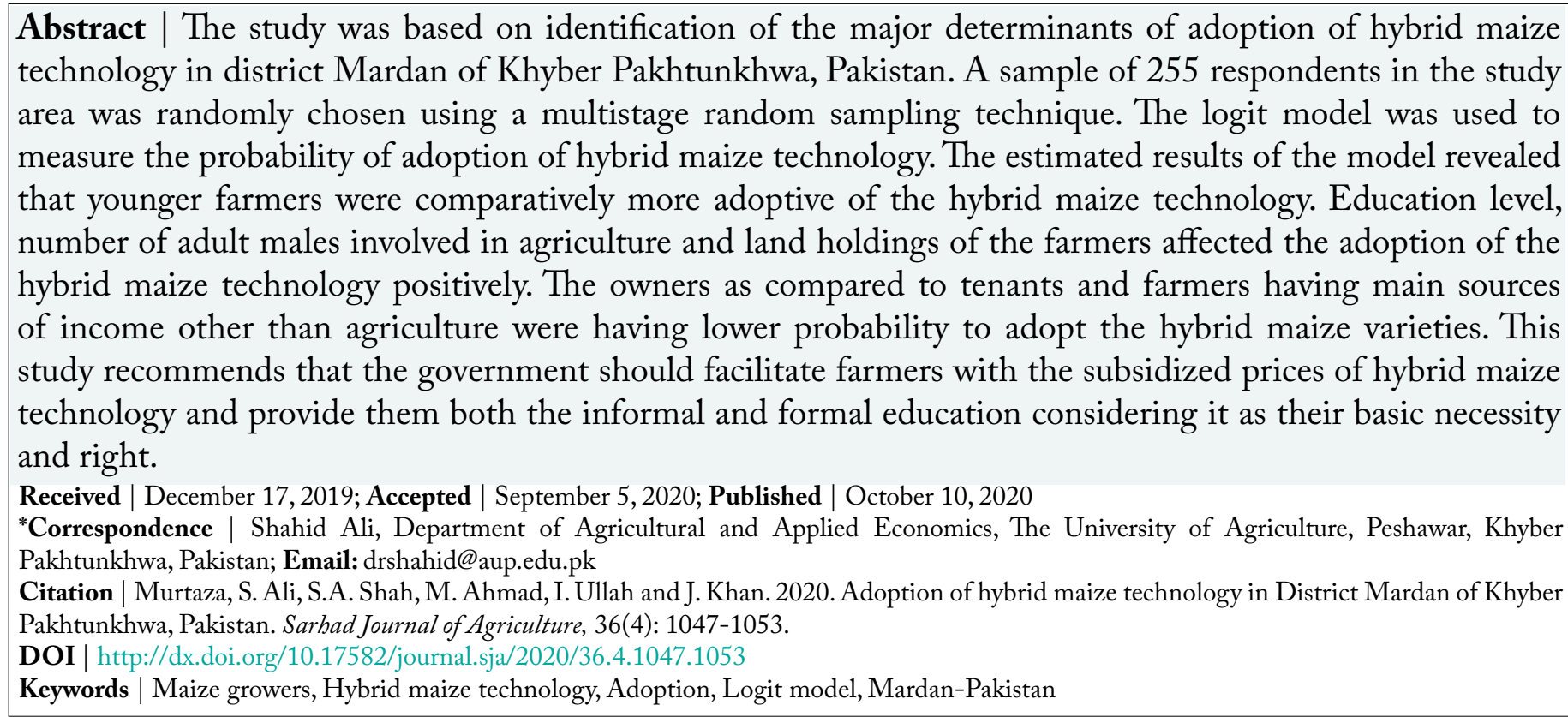

\section{Introduction}

A griculture sector being a major source of earning has an important role in any country's economy. According to the Economic Survey of Pakistan, this sector shares $18.5 \%$ to GDP and provides employment to $38.5 \%$ of the total labor force (GoP, 2019). The sector is further divided into sub-sectors like forestry, crops, fisheries and livestock. The contribution of crops to the agriculture sector was recorded as $58.33 \%$, highest among all the sub-sectors followed by livestock, forestry and fisheries (GOP, 2018). The subsector crop is further categorized as the minor and minor crops. Sugarcane, cotton, rice, maize and wheat are referred as the major crops, while the rest of the crops are included in the minor crops.
Maize (Zea mays L.) belongs to the family Poaceae and it is the third largest crop among the major cereal crops grown in the world (FAO, 2018). It is a C-4 plant and has a high genetic potential to grow in dry and hot climatic conditions. Its grain consists of 79 percent starches, 10 percent proteins, 4 percent fats, 4 percent fiber and 3 percent essential mineral deposits (Ahmad et al., 2017). Maize is widely cultivated for two main reasons; food and feed for animals, and in raw form, it is also used in several industries for making corn oil and starches, corn syrup and flakes, cosmetics, bakers, alcohol and wax.

World's production of maize in 2017 was about 1,060 million tons as it was grown on 188 million hectares of land. USA contributed the highest share of about 
371 million tons to the global production followed by countries like China, Brazil, Ukraine and Argentina (FAO, 2017). The global average maize yield that year was recorded as 5.63 tons per hectare. Pakistan was ranked as the $17^{\text {th }}$ largest maize producer worldwide with the production of about 6.13 million tons cultivated on 1,340,000 hectares of land. The average yield of maize in Pakistan was recorded as 4.6 tons/ ha; comparatively low than the worlds average by 1.03 tons/ha (GOP, 2018). Maize in 2018 was grown on 1.2 million hectares of cultivable land, declined by $8.8 \%$ over the previous year's area and the production recorded in that year was about 5.07 million tons which shows a decline of $7 \%$ over the previous year's production (GOP, 2018). In Khyber Pakhtunkhwa, a $1.19 \%$ increase in the area cultivated under maize was recorded during the year 2015-16 as compared to the previous year but a decline of $4.03 \%$ in production was recorded that year due to heavy rain and floods in the province Government of Khyber Pakhtunkhwa (GOKP, 2016). Maize yield in district Mardan was recorded as 3.09 tons per hectare, the highest among all the other districts of the province due to adoption of the hybrid maize varieties and modern technology (GOKP, 2016). Advanced hybrid technology of maize crop is quite capable of increasing production by reducing the losses caused by weeds, insects and other pests. Since the introduction of genetically modified maize in the late 1990's, the farming community willingly shifted to adopt the hybrid maize technology for its higher economic return and higher production of 80-120 mounds per acre (Arain, 2013). Maize crop in Pakistan is grown twice in a year and its yield has been increased in some areas from the last few years due to the use of hybrid maize varieties but the adoption of this hybrid maize technology is just limited to 34 percent in the country because of its higher prices in the market (Khan, 2017). Lower prices of hybrid maize varieties will lead to higher adoption and thus the higher production.

Adoption of hybrid maize technology in Khyber Pakhtunkhwa is comparatively low that results in lower production and yield which threatens the farming community and the current demand for maize. This low adoption might be due to lack of awareness in farming community regarding the modern production technologies. More research work is required on adoption of such new technologies as no similar studies have been conducted in the study area. Therefore, this study is focused on examining adoption of hybrid maize technology and identification of the major determinants that affect the adoption of hybrid maize technology in district Mardan of Khyber Pakhtunkhwa, Pakistan.

\section{Objectives of the study}

1. To study the socio-economic characteristics of maize growers in district Mardan.

2. To examine and identify the major determinants that affect the adoption of hybrid maize technology in district Mardan.

\section{Hypotheses of the study}

Hypothesis 1: $\mathrm{H}_{0}$ : Age and education has no significant effect on adoption of hybrid maize technology; $\mathrm{H}_{1}$ : Age and education has a significant effect on adoption of hybrid maize technology.

Hypothesis 2: $\mathrm{H}_{0}$ : Source of income and land holdings have no significant effect on adoption rate; $\mathrm{H}_{1}$ : Source of income and land holdings have significant effect on adoption rate.

\section{Data and methodology}

Study area: This study was conducted in Mardan, the second largest and a hot semi-arid district of Khyber Pakhtunkhwa, located in the center of the province with $34^{\circ} 12^{\prime} 0$ (degree) to the North and $72^{\circ} 1^{\prime} 60$ (degree) to the East with an altitude of 283 meters (Figure 1). The total geographical area of the district is $1,632 \mathrm{~km}^{2}$ and its total population was recorded as 358,604 (GOP, 2017). District Mardan is well known for its archeological sites and agriculture. The district is blessed with the productive lands and suitable agroclimatic conditions, favorable for the cultivation of major crops like wheat, maize, tobacco and sugarcane.

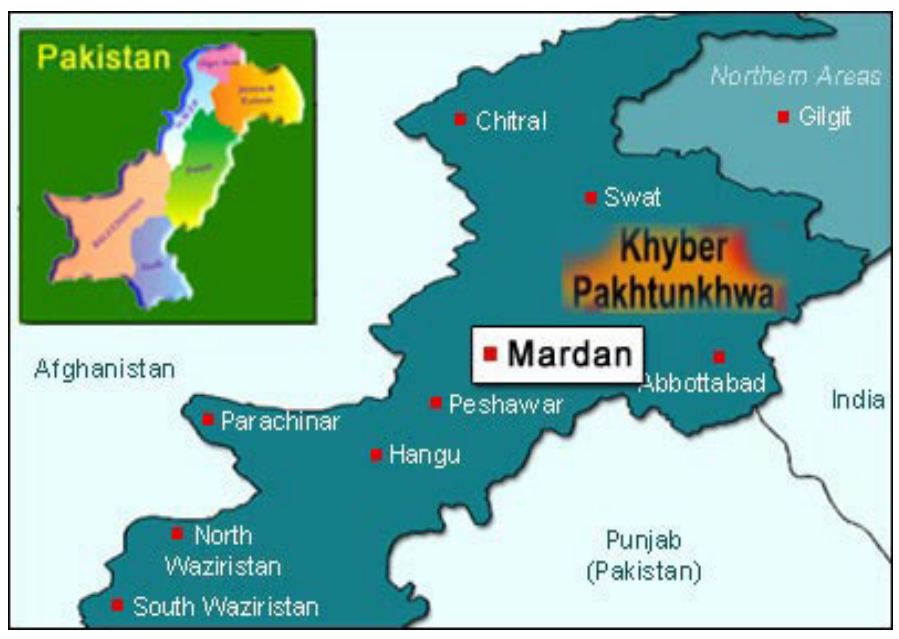

Figure 1: Location of the study area; Sampling procedure and sample size. 
The research study was based on cross-sectional data and was taken from 255 maize growers using a well-designed questionnaire after pre-testing it in the field. A multistage sampling technique was used after choosing the Mardan district purposively. In the early stage, tehsil Mardan was chosen randomly. In the next stage, five villages namely Sawaldher, Rustam, Chargalli, Narshak and Gujjarat were chosen randomly among the major maize producing villages and in the last stage, a total of 255 respondents (63 from village Narshak, 57 from Rustam, 48 from Sawaldher, 45 from Chargalli and 42 respondents from Gujjarat) were randomly selected using Proportional Allocative Sampling technique, given below.

$$
n i=\frac{N i}{N} \times n
$$

Where;

$\mathrm{N}=$ total no. of respondents in the chosen villages; $\mathrm{Ni}=$ no. of maize-producers in the $\mathrm{i}^{\mathrm{th}}$ village; $\mathrm{n}_{\mathrm{i}}=$ no. of maize-producers to be chosen in the $i^{\text {th }}$ village; $n=$ no. of sampled maize-producers to be chosen from all the randomly selected villages.

\section{Conceptual framework}

The selection of the regression model depends upon the nature of the dependent variable whether it is qualitative or quantitative. Usually there are three approaches to analyze the probability when the dependent variable is qualitative such as gender, marital status or adoption of a specific production technology etc. First the Linear Probability Model (LPM) can be used but it suffers several problems like normality, heteroscedasticity and questionable $\mathrm{R}^{2}$ value. The main disadvantage of the LPM is that it doesn't guarantee whether the probability will lie between 0 and 1 (Gujarati and Porter, 2009). To overcome such problems, logit and probit models were introduced. The logit model follows the logistic cumulative distribution, while the probit model follows the normal cumulative distribution. Though both are the same but there is a slight difference in logistic distribution as it has heavier tails than that of the normal cumulative distribution (Ahmad et al., 2001). In current study, a logit model was used as most of the researchers such as Banerjee and Martin (2009), Aneani et al. (2012), Challa and Tilahun (2014) and Dhraief et al. (2018) used the binary logit model because of its comparative simplicity.
The logit model was first introduced for the purpose of describing the growth in population and the name logit was given to it by Verhulst, a Belgian mathematician (Wilson and Lorenz, 2015). Later on, the model was developed by a British statistician David Cox in 1958 (Walker and Duncan, 1967). The S-shaped logit and probit curves shown in Figure 2 represent the cumulative distribution function that is used to model the regressions in which the dependent variable is dichotomous in nature with $0-1$ values. The figure reveals that the value of $Z_{i}$ ranges between $+\infty$ and $-\infty$ while the probability value ranges between 0 and 1 (Gujarati and Porter, 2009).

Probability for a dichotomous variable taking the value of 1 can be calculated as:

$$
P_{I}=\frac{1}{1+e^{-z_{i}}}
$$

Where;

$P_{I}$ is the probability of the specific variable taking the value of $1 ; Z_{i}=\beta i X i+\mu i$

While probability of the variable taking value of 0 can be calculated as:

$$
1-p_{i}=\frac{1}{1+e^{z_{i}}}
$$

The odd ratio for Equations 2 and 3 is specified as:

$$
\frac{p_{i}}{1-p_{i}}=\frac{1+e^{z_{i}}}{1+e^{-z_{i}}}=e^{z i}
$$

Here $p / 1-p$ represents the odd ratios. Equation 4 has a non-linear relationship that might results the gruesome estimates, so taking the log of odd ratio will get it to the linear form. The equation for $\log$ of odd ratio is given as:

$$
L_{i}=\ln \left[\frac{p_{i}}{1-p_{i}}\right]=\beta_{0}+\beta_{i} X_{i}
$$

Equation 5 represents the log of odd ratio, the logit that is linear both in $X$ and $\beta_{s}$. Now probabilities can be easily found out by logistic regression-model. General form of the logit-model is given as:

$$
Y i=\beta i X i+\mu i \quad \ldots(6)
$$


Where;

$\mathrm{Yi}$ is the dependent variable; $\beta$ s are the parameters to be estimated; $\mu$ is the error term.

\section{Specified form of the logit-model}

The model used in this research work is given below.

Seedtech $=\beta_{0}+\beta_{1}$ lnAge $+\beta_{2}$ lnEducation $+\beta_{3}$ Adultmale $+\beta_{4}$ lnIncome $+\beta_{5}$ lnFarmsize $+\beta_{6}$ DTenancystatus $+u_{i}$

Where;

Seedtech $=$ maize seed technology $(1$ for hybrid, 0 otherwise); Age = respondents' age in years; Education $=$ level of education in years; Adult male $=$ no. of adult male involved in agriculture; Income = primary source of income ( 1 for agriculture, 0 otherwise); Farm size = landholding by the respondents; DTenancy status= Dummy variable (1 for owner, 0 otherwise); $\mathrm{Ln}=$ natural $\log ; \beta s=$ parameters to be estimated; ui = error term.

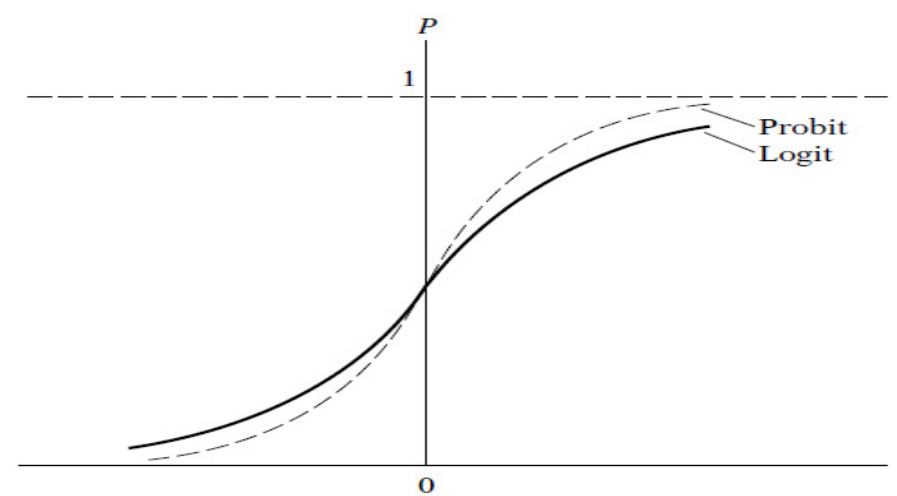

Figure 2: Cumulative distribution function.

Source: Gujarati and Porter, 2009.

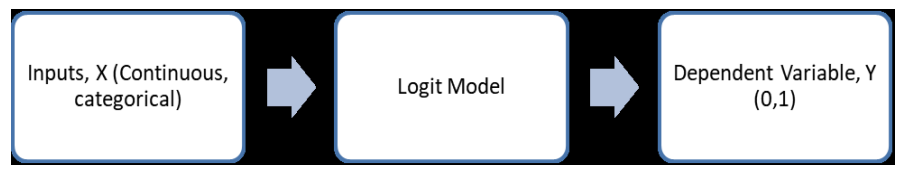

Figure 3: Graphical presentation of the model.

\section{Results and Discussion}

\section{Socio-economic characteristics}

Socio-economic characteristics like age, education, farm size, income's source, and tenancy status etc. are the factors that affect the thinking and decision making power of an individual regarding the adoption of a specific technology. The results in Table 1 showed that the mean sampled farmers' age was 49.04 years, having minimum and maximum years of 25 and 82, respectively. The mean education level of the interviewed farmers was 4.58 schooling years and mean land holding was recorded as 3.29 acres. On average there were 3.26 adult male per family involved in agriculture. Among the sampled respondents, about $130(51 \%)$ respondents were those who were having agriculture as a primary source of income and about $84(33 \%)$ of the respondents were owners of their own land and they personally were involved in agriculture in their lands while remaining $67 \%$ of the respondents were tenants and owner-cum tenants.

\section{Adoption of hybrid maize technology}

Table 2 presents the percentage of sampled respondents who adopted the hybrid maize technology in the study-area. It was observed that a majority of the maize growers in the study area $(59.25 \%)$ adopted the hybrid varieties. Out of 63 maize growers in village Narshak, 43 (68.25\%) respondents were practicing the hybrid maize technology. The adoption of hybrid maize technology as compared to other villages was highest in Narshak followed by villages namely Sawaldher with 27 (56.25\%), Rustam with 31 (54.38), Chargalli with 23 (51.11\%) and Gujjarat with $19(45.23 \%)$ adopters of hybrid maize varieties out of 48, 57, 45 and 42 maize growers. Besides, almost all the maize growers in the study area were aware and in favor of using the modern production technologies such as row to row and plant to plant to plant distancing, application of recommended fertilizers, weedicides and pesticides.

\section{Table 1: Socio-economic characteristics.}

$\begin{array}{llll}\text { Variables } & \text { Mean } & \text { Maximum } & \text { Minimum } \\ \text { Age (Years) } & 49.04 & 82 & 25 \\ \text { Education (Years) } & 4.58 & 16 & 0 \\ \text { Adult male (No) } & 3.26 & 12 & 1 \\ \text { Farm-size (No) } & 3.29 & 11 & 1 \\ \text { Income source } & 0.51 & 1 & 0 \\ \text { Tenancy status } & 0.33 & 1 & 0\end{array}$

Source: Authors' estimates from survey data, 2018.

Table 2: Adoption of bybrid maize technology.

$\begin{array}{llll}\text { Villages } & \begin{array}{l}\text { Hybrid } \\ \text { seeds }\end{array} & \begin{array}{l}\text { Conventional } \\ \text { seeds }\end{array} & \begin{array}{l}\text { \%(Hy- } \\ \text { brid) }\end{array} \\ \text { Narshak } & 43 & 20 & 68.25 \\ \text { Rustam } & 31 & 26 & 54.38 \\ \text { Sawaldher } & 27 & 21 & 56.25 \\ \text { Chargalli } & 23 & 22 & 51.11 \\ \text { Gujjarat } & 19 & 23 & 45.23 \\ \text { Total } & 151 & 104 & 59.25\end{array}$

Source: Authors' estimates from survey data, 2018. 
Table 3: Estimates of logistic regression and marginal effects.

\section{Regressors}

\section{Age}

Education

Adult-male

Income's source

Farm-size

Tenure status

Constant

Log likelihood

LR chi $^{2}$

$\mathrm{P}$-value

Pseudo $\mathrm{R}^{2}$

\section{Estimates of logit}

\section{Coefficients}

z-test

$-2.92^{* * *}$

$2.22^{*}$

5.02

$3.68^{* *}$

$2.47^{* *+}$

$-1.85$

$-1.86$

$-1.7598$

0.2912

$-0.6516$

$-1.86$

p-value

0.004

0.026

0.00

0.00

0.013

0.064

0.063

$-114.6632$

115.47

0.000

0.3349

Marginal effects

$\begin{array}{lll}\text { Coefficients } & \text { z-test } & \text { p-value } \\ -0.0076 & -3.10^{* *} & 0.002 \\ 0.0135 & 2.30^{*} & 0.022 \\ 0.037 & 5.42^{* *} & 0.000 \\ 0.1785 & 4.10^{* *} & 0.000 \\ 0.0428 & 2.59^{* *} & 0.010 \\ -0.0959 & -1.90^{*} & 0.057\end{array}$

Source: Authors' estimates from survey data, 2018.

\section{Estimates of logistic regression}

The maximum likelihood estimates of the binary logistic regression, given in Table 3 presented the major determinants of adoption of hybrid maize technology. The coefficient of each and every explanatory variable associated with its $\mathrm{z}$-statistic and $\mathrm{p}$-value shows the $\log$ of odd ratio of that specific variable for the adoption of hybrid maize technology.

The estimated results revealed that age, education, no. of adult male involved in agriculture, primary source of household's income and land holdings were highly significant at statistic value of $\alpha=0.05$ whereas tenure-status was significant at $10 \%$. Age with the coefficient of -0.052 revealed that one year increase in age decreased the logit in favor of adoption of hybrid maize variety by $5.2 \%$ and it might be due to the reason that aged people often are scared of unseen risks associated with the use of new technologies. The results are in accordance to Wang et al. (2017), Sánchez-Tolendano et al. (2018) as their research work revealed that young farmers are more adoptive to hybrid maize technology than the aged ones. A unit increase in education had a positive and significant effect on adoption of hybrid maize varieties and a unit increase in years of schooling increased the probability of adopting such varieties by 9.2\%. Gregory and Sewando (2013) also encountered the positive and significant effect of schooling years on adoption of hybrid maize varieties. Factors like no. of male adult involved in agriculture and farm size increased the $\log$ of odd ratios in favor of hybrid maize technology by $19.3 \%$ and $29.1 \%$ respectively. Raghu et al. (2015) estimated the same positive and significant effect of farm size on adoption rate. The estimated 1.21 coefficient of income's source revealed that the respondents having agriculture as a primary source of income were more adoptive to hybrid maize varieties as compared to others. The log of odd ratio in favor of hybrid maize varieties for owners was 0.65 times less than the estimated coefficient of tenure status as it was -0.651 .

\section{Marginal effects}

The estimates of marginal effects showed that almost all the explanatory variables were statistically significant at $\alpha=0.05$. Age with the predicted coefficient of -0.0076 showed the higher probability of adopting the hybrid maize technology by younger farmers than the aged ones and the results are in accordance to Wang et al. (2017). An increase in household's land holdings and education level showed the $4.2 \%$ and $13.3 \%$ higher probability of adopting the hybrid maize technology and these results are in accordance to Sánchez-Tolendano et al. (2018). The estimated coefficient of 0.037 for adult male revealed that an increase in no. of adult male involved in agriculture increased the probability of adopting the hybrid maize varieties by $3.7 \%$. The estimated coefficients of income's source and tenure status showed the higher probability of adopting the hybrid varieties by $9.5 \%$ and $17.8 \%$ for the tenants depending on agriculture as a primary source of earning as compared to others. 
Results of the logit model revealed that younger farmers were comparatively more adoptive of the hybrid maize technology. Education level, number of adult male involved in agriculture and land holdings of the farmers affected the adoption of the hybrid maize technology positively. Tenants as compared to owners and respondents who mostly depended upon agriculture as the main income's source had a higher probability to adopt the hybrid maize varieties. This study recommended that farmers should be facilitated with the subsidized prices of hybrid maize technology, with both the informal and formal education to improve the adoption rate. Besides, the study recommends the local extension department to make the farmers aware of modern production technologies such as soil testing, proper seed bed preparation, row to row and plant to plant distancing, and appropriate and in-time use of essential fertilizers and pesticides to improve production.

\section{Limitations of the study}

1. There is always a risk of sampling errors while using a probability sampling technique (as used in this study) because it does not reflect the general population concerned and results in "sample bias". Scientific calculation tools would be a better choice for researchers to draw an appropriate sample.

2. The study was unable to address an important factor of "extension workers' role in rate of adoption" and is needed to be addressed in future studies.

3. As the study was limited to a single district, Mardan, of Khyber Pakhtunkhwa province. Findings and recommendations of the study are not needed to be carefully generalized to the whole province or country.

\section{Novelty Statement}

This study loomed out the perception of farming community regarding innovative agronomic practices and modern agriculture. Findings of this study are expected to help farmers in boosting up maize production using contemporary and pre-eminent available resources.

\section{Author's Contribution}

Murtaza developed main theme of the study and wrote introduction. Shahid Ali reviewed literature, wrote conceptual framework and specified the model. Syed Attaullah Shah estimated the model and interpreted the results. Mehran Ahmad collected the primary and secondary data and punched in excel sheet. Irfan Ullah wrote conclusion and corrected references. Jahangir Khan helped in witting results and discussion, recommendations and abstract.

\section{Conflict of interest}

The authors have declared no conflict of interest.

\section{References}

Ahmad, B., M. Ahmad, M.A. Chaudhry and S. Hassan. 2001. An analysis of cotton leaf curl virus disease in Pakistan's Punjab. Pak. J. Agric. Sci. 38(2): 1-16.

Ahmad, N., and D.K. Sinha, K.M. Singh, and R.R. Mishra. 2017. Growth performance and resource use efficiency of maize in Bihar: An economic perspectives. Department of agricultural economics. Dr. Rajendra Prasad Central Agricultural University, Pusa-Samastipur-848125, Bihar, India. MPRA Paper No. 80267, posted 22 Jul 2017 08:50 UTC

Aneani, F., V.M. Anchirinah, F. Owusu-Ansah and M. Asamoah. 2012. Adoption of some cocoa production technologies by cocoa farmers in Ghana. J. Sustain. Agric., 1(1): 103-117. https://doi.org/10.5539/sar.v1n1p103

Arain, G., 2013. Maiz (Corn) cultivation in $\mathrm{Pa}-$ kistan. Crop manager-agronomy center pivot irrigation system valley irrigation Pakistan (private), limited.

Banerjee, S. and S.W. Martin. 2009. A binary logit analysis of factors impacting adoption of genetically modified cotton. Ag. Biol. Forum., 12(2): 218-225.

Challa, M. and U. Tilahun 2014. Determinants and impacts of modern agricultural technology adoption in west Wollega: The case of Gulliso district. J. Biol. Agric. Healthc., 4(20): 63-77.

Dhraiefa, M.Z., S. Bedhiaf-Romdhania, B. Dhehibib, M. Oueslati-Zlaouia, O. Jebalia and S.B. Youssef. 2018. Factors affecting the adoption of innovative technologies by livestock farmers in arid area of Tunisia. FARA Res. Rep., 4(5): 
1-22. https://doi.org/10.30682/nm1904a

FAO, 2018. Food and agriculture organization. FAO statistcal year book, www.fao.org.

GoKP, 2016. Development Statistics of Khyber Pakhtunkhwa, 2016. Bureau of statistics, planning and development department of Khyber Pakhtunkhwa. www.kpbos.gov.pk

GOP, 2017. Economics survey of Pakistan, 201617. Economic Advisory Wing, Finance Division, Islamabad, Pakistan.

GoP, 2018. Economics survey of Pakistan, 2017-18 (and various previous issues). Economic Advisory Wing, Finance Division, Islamabad, Pakistan.

GoP, 2018-19. Economics survey of Pakistan, 2018-19. Economic Advisory Wing, Finance Division, Islamabad, Pakistan..

Gregory, T. and P. Sewando. 2013. Determinants of the probability of adopting quality protein maize (QPM) technology in Tanzania: A logistic regression analysis. Int. J. Sust. Dev. World, 2(2): 729-746.

Gujarati, D.N. and D.C. Porter. 2009. Basic econometrics, $5^{\text {th }}$ edition. Mc Graw Hill Inc., New York.

Khan, M., K. Khan, S. Afzal, N. Ali, M.M. Anjum, H. Usman and M.O. Iqbal. 2017. Seed yield performance of different maize (Zea mays L.) genotypes under agro climatic conditions of Haripur. Int. J. Environ. Sci. Nat. Res., 5(5): 1-6. https://doi.org/10.19080/ IJESNR.2017.05.555672

Raghu, P.T., O. Erenstein, C. Böber and V.V. Krishna. 2015. Adoption and outcomes of hybrid maize in the marginal areas of india. Jarq. Jpn. Agric. Res. Q. 54(2): 189-214.

Sánchez-Toledano, B.I., Z. Kallas, O.P. Rojas and J.M. Gil. 2018. Determinant factors of the adoption of improved maize seeds in southern Mexico: A Survival Analysis Approach. Sustainability, 10(10): 1-22. 3543. https://doi. org/10.3390/su10103543

Walker, S.H. and D.B. Duncan. 1967. Estimation of the probability of an event as a function of several independent variables. Biometrika, 54(1-2): 167-179. https://doi.org/10.1093/ biomet/54.1-2.167

Wang, Y., J. Vitale, P. Park, B. Adams, B. Agesa and M. Korir. 2017. Socioeconomic determinants of hybrid maize adoption in Kenya. Afr. J. Agric. Res., 12(8): 617-631. https://doi.org/10.5897/ AJAR2016.11958

Wilson, J.R. and K.A. Lorenz. 2015. Modeling binary correlated responses using SAS, SPSS and R, Springer. Series: ICSA book series in statistics. https://doi.org/10.1007/978-3-31923805-0 